\title{
РОССИЯ И ПЕРЕМЕННАЯ «США» В ДЕСЯТИЛЕТНЕМ КОНФЛИКТЕ ВОКРУГ ЯДЕРНОЙ ПРОГРАММЫ ИРАНА
}

\begin{abstract}
Аннотация: Занимая промежуточную позицию, Россия в десятилетнем конфликте вокруг ядерной программы Ирана старалась обеспечить свои интересы в обеих сторонах - Иране и Западе. Вопреки ее утверждению о том, что подобная политика является принципиальным и самостоятельным действием в комплексном пространстве, зависимость политики Москвы от переменной «США» и представление о малом значении другой части этого уравнения - Ирана - являются заметными дефектами данной политики. В конечном счете, и без учета некоторых тактических изменений, роль Москвы в иранской ядерной программе была не больше, чем игрой в сконструированных США рамках. По этой причине, осознание Кремлем стратегических иелей давления на Тегеран, которые проявляются в попытках Вашингтона координировать Иран со своей долгосрочной экспансионистской политикой на Ближнем Востоке, не проявилось в «практической» политике России. Такая политика не согласуется и с принципами, провозглатенными Москвой: о несогласии с экспансионизмом США и действиями в качестве «самостоятельной великой державы». В качестве методологической базы в данной статье использован системный анализ политики России в отношении ядерной программы Ирана и поэтому детали не рассматривались. Недавние события на региональном и международном уровнях, имеющие влияние на ядерную программу Ирана в том числе отномении США и России и продолжение агрессивной политики США на Ближнем Востоке проектом «Нового Большого Ближнего Востока» с одной стороны, и текущие переговоры по Иранской ядерной программе, продолжение угроза военного удара по Ирану и тоже новые прогрессы в ядерной деятельности этой стране с другой стороны, создали новую ситуацию по отночению к этой теме.
\end{abstract}

Ключевые слова: война, санкиии, Дипломатия, переговоры, Ближний Восток, экспансия, Иран, ядерная программа, Россия, США.

\section{Введение}

Вслед за увеличением концентрации внимания на ядерной программе Ирана (ЯПИ) за последнее десятилетие (2003-2013), Россия, как и другие субъекты, также оказались вовлечены в эту тему и попытались обеспечить свои различные интересы. Предполагая угрозы и возможности в этой теме и занимая промежуточную позицию, Москва была намерена удовлетворить эти интересы в обеих сторонах — и в Иране, и на Западе.

Так Россия, с одной стороны, соглашаясь с Тегераном, признала право Ирана на мирное использование ядерной энергии и выступала против односторонних санкций и угрозы военного действия против Ирана ${ }^{1}$, а, с другой, в соответствии с линией Запада подчеркнула существование неопределенности относительно ЯПИ и настаивает на необходимости принятия соответствующих мер Тегераном, чтобы устранить все озабоченности по этому вопросу².

Обзор политики России в этот период показывает, что хотя она, как и Западные державы, не скрывает своего беспокойства по поводу вероятности переключения ЯПИ на военные цели, Россия также по-

\footnotetext{
Глава МИД РФ Сергей Лавров: итоги года // Интерфакс http://www.interfax.ru/txt.asp?id=283171, 27.11.2012.

2 РФ рассчитывает на выполнение Ираном обязательств по ядерной программе // РИА Новости - http://ria.ru/ politics/20120417/628229087.html, 17.04.2012.
} 
дозревала Запад в намерениях давить на Иран. В то же время, предлагая поэтапный план и действуя в качестве инициатора, Москва была намерена принять промежуточное решение. Этими действиями Россия попыталась представить себя как активного игрока и подчеркнуть свою важную роль и для Ирана и для Запада.

Вопреки ее утверждению о том, что эта политика является принципиальной, она в целом обнаруживает дефекты, наиболее важным из которых, является зависимость данной политики от фактора США и отношений Москвы с Вашингтоном. Взлеты и падения в этих отношениях (в период президентства от Путина к Медведеву и затем снова к Путину) и заметное воздействие этого на позицию Москвы по ЯПИ являются доказательством этого утверждения.

Наличие подобного воздействия проявляется в таких изменениях доминирующего положения в Москве о ЯПИ, как акцент на мирную ЯПИ в конце первого и во второй период президентства Путина (в условиях охлаждения отношений между Россией и США), более тесное сотрудничество Москвы с Вашингтоном в оказании давления на ЯПИ, например, одобрение санкционных резолюций против Ирана в период президентства Медведева (в условиях «перезагрузки» в отношениях России и США) и акцент Кремля на то, что не существует данных о военной направленности ЯПИ ${ }^{3}$ в третий период президентства Путина (в условиях обострения отношений между Россией и США).

И хотя Россия на основе логики международной политики и в пределах своих компетенций по теме ЯПИ не могла быть полностью независимой от доминирующих тенденций в системе международных отношений, в частности, от соображений гегемона этой системы (США), а также учитывая склонность России к кооперации с Вашингтоном в целях получения больших преимуществ, что является вполне разумным выбором, все же кажется, что зависимость действий России от фактора США, во-первых, в большинстве случаев, не основано на реальном положении, а, во-вторых, не соответствует общим принципам внешней политики Москвы.

Таким образом, в процессе оценки присутствия России в десятилетнем конфликте по ЯПИ будет полезно ответить на такие вопросы, как: Какова

\footnotetext{
3 Лавров: ни у кого нет данных о военной направленности программы Ирана // РИА Новости — http://ria.ru/ world/20131008/968628455.html, 8.10.2013.
}

позиция и каковы интересы России в этом конфликте? До какой степени Москва могла участвовать в определении правил игры? Политика России была независимой? Каковы дефекты политики России? Каковы необходимые условия для самостоятельных действий России?

Обзор комментариев официальных лиц Ирана, России и Запада и также научных работ по этой теме показывает, что существуют разногласия в ответах на эти вопросы. Правильные ответы на поставленные вопросы, безусловно, поспособствуют более эффективному регулированию отношений между Ираном и Россией. Тем более, что в период президентства Хасана Рухани, «тактических» изменений в политике Тегерана по ЯПИ очевидное воздействие ЯПИ на другие аспекты отношений Тегерана и Москвы на двусторонних, региональных и международных уровнях неоспоримо.

\section{Соображения и интересы России по ядерной проблеме Ирана}

Москва различными методам и тактиками пыталась реализовать свои интересы в ЯПИ. Эта разница просматривается в ряде положений: с одной стороны, поддержка Москвой резолюций СБ ООН против Ирана, акцент на то, что ЯПИ не соответствует полностью требованиям резолюций СБ $\mathrm{OOH}^{4}$, заявление Медведева о приближении Ирана к обладанию потенциалом создания ядерного оружия 5 , акцент на то, что Иран игнорирует требования международного сообщества в отношении своей ядерной программы ${ }^{6}$, а с другой стороны, акцент на право Ирана на мирное использование атомной энергии ${ }^{7}$, акцент на то, что нет данных, подтверждающих наличия в ЯПИ военной составляющей ${ }^{8}$, признание

\footnotetext{
4 Позиция «шестерки» в Алма-Ате должна быть привлекательна для Ирана // Интерфакс - http://www.interfax.ru/txt. asp?id=290722, 15.02.2013

5 Медведев: Иран Приближается к Возможности Создания Ядерного Оружия // РИА Новости -http://www.rian.ru/ world/20100712/253947885.html, 12.07.2010.

6 МИД РФ: Иран игнорирует требования международного сообщества // Вести - http://www.vesti.ru/doc.html?id=680733, 13.01.2012.

7 Путин признает право Ирана на мирный атом // Интерфаксhttp://www.interfax.ru/world/news.asp?id=328711, 13.08.2013.

8 РФ рассчитывает на выполнение Ираном обязательств по ядерной программе // РИА Новости - http://ria.ru/ politics/20120417/628229087.html, 17.03.2012
} 


\section{Национальная безопасность - № 2(31) • 2014}

права Ирана на обогащение урана ${ }^{9}$, акцент на непрофессиональный и предвзятый подход доклада 8 ноября 2011 Международного агентства по атомной энергии (МАГАТЭ) $)^{10}$ и неоднократный акцент на мирное урегулирование ЯПИ.

Россия, применяя эту тактику, старается удовлетворить три важных интереса:

1. Предотвращение милитаризации ЯПИ и обладания Тегераном ядерным оружием

2. Предотвращение военных действий против Ирана

3. Предотвращение выведения Ирана на орбиту США в результате оказанного на него давления

\section{1. Предотвращение обладания Ираном ядерным оружием}

Многие русские политики и аналитики утверждают, что переключение ЯПИ на военные цели не только приводит к потенциальной военной угрозе безопасности России, но и способствует возникновению региональных и международных вызовов, которые затрагивают интересы России. К этим негативным последствиям относятся ослабление Договора о нераспространении ядерного оружия (ДНЯО) и международных норм нераспространения на Ближнем Востоке и в мире, стимулирование гонки (ядерных) вооружений на Ближнем Востоке, и повышения концентрации внимания на Тегеране со стороны западных держав и Израиля и вероятность войны.

Эти проблемы повышают напряженность и нестабильность на Ближнем Востоке, в прилегающих регионах России (Центральная Азия, Южный Кавказ и Каспийский регион) и, следовательно, на южных границах России. Следует отметить, что, хотя Тегеран неоднократно настаивал, что его ядерная программа носит исключительно мирный характер, некоторая неясная деятельность в ядерной сфере и несоответствие объема ядерной деятельности заявленным мирным целям в России рассматривают

\footnotetext{
9 Путин Владимир. Россия и Меняющийся Мир - http://www. mn.ru/politics/20120227/312306749.html, 27.02.2012.

10 Комментарий Департамента информации и печати МИД России относительно вышедшего 8 ноября нового доклада Гендиректора МАГАТЭ Ю.Амано по иранской ядерной программе // Пресс-служба МИД России. 1737 - http://www. mid.ru/brp_4.nsf/0/7AA0429FED84FBCD44257943005CC5 EA, 9.11.2011.
}

как доказательства, что Иран намеревается создать ядерную бомбу11.

Хотя, некоторые в России полагают, что Иран стремится к развитию ядерной технологии до такого уровня, который позволит ему в трудный час быстро создать подобное оружие ${ }^{12}$, но некоторые другие открыто говорят о решимости Ирана обладать ядерным оружием $^{13}$.

Владимир Сажин объясняет, что если ядерное оружие будет разработано Ираном, то конфликт на Ближнем и Среднем Востоке неизбежен ${ }^{14}$. Критикуя мнение Путина о «праве Ирана обогащать уран» (цитата из статьи Путина в «Московских новостях»), Владимир Милов предупреждает о появлении новой ядерной державы возле границ России ${ }^{15}$.

Также, российские власти неоднократно высказывали позицию против приобретения Ираном ядерного оружия. Владимир Путин в июне 2012 года сказал; «Мы всегда поддержсивали право иранского народа ... на мирное использование атомной энергии. Но я хочу подчеркнуть, что именно на мирное использование. ... . Мы очень последовательные приверженцы нераспространения оружия массового уничтожения, ...» ${ }^{16}$. Лавров в сентябре 2012 года заявил; «Что касается Ирана, то Россия, как и США, выступает категорически против нарушения режима распространения ядерного оружсия» ${ }^{17}$.

Следует отметить, что многие российские аналитики согласны с тем, что растущие угрозы вокруг

\footnotetext{
11 Николаева Карина и Ковалев Георгий. Иранский Компромисс — http://www.politcom.ru/15054.html, 19.12.2012.

12 Седов Дмитрий. МАГАТЭ и «туалетное дело» - http:// www.fondsk.ru/news/2012/02/23/magate-i-tualetnoe-delo.html, 23.02.2012.

13 Арбатов А. Г. Ползучий Кризис // Азия и Африка сегодня. № 8. Август и Сентябрь 2012. ст. 11; См. сн. 11; Yevseyev Vladimir. Tough talks with Iran lie ahead in Moscow - http:// valdaiclub.com/asia/44481.html, 15.06.2012.

14 Манина Дарья. Итоги Года. Чем обогащается Иран — http:/ rus.ruvr.ru/2012_12_22/ITOGI-GODA-CHem-obogashhaetsjaIran/, 22.11.2012.

15 Милов Владимир. Сказка о злобном Западе - http:// www.vedomosti.ru/opinion/news/1518088/vostok_est_vostok, 29.02.2012.

16 Путин: Россия поддерживает право Ирана на мирный атом // Вести — http:/www.vesti.ru/doc.html?id=815336\&cid=5, 7.06.2012.

17 Лавров увидел в санкциях США против Ирана и Сирии угрозу российскому бизнесу // Лента.Ру — http://lenta.ru/
} news/2012/09/08/interests/, 8.09.2012. 
Ирана спровоцируют Тегеран на создание ядерной бомбы с целью защитить себя. Эти угрозы включают опыт ирано-иракской войны и поддержка странами региона и Западом Саддама Хуссейна, две военных операции США и их союзников в Афганистане и в Ираке, усиление военного присутствия Запада в регионе, в результате чего Иран находится в фактическом геополитическом окружении между западными войсками и военными базами, постоянная угроза со стороны Израиля и США предпринять превентивные военные действия против ядерных объектов Ирана. Они убеждены, что продолжение угроз делает Иран более решительным в создании ядерного оружия.

\section{2. Предотвращение военных действий против Ирана}

В России многие предупреждают о широких и непредсказуемых воздействиях возможной войны против Ирана на региональном и даже международном масштабах. Такая озабоченность касается, прежде всего, вероятности неизбежного распространения угроз и нестабильности на Южном Кавказе, Центральной Азии и Каспийском регионе, и, следовательно, на южных границах России.

Также Россию не может не беспокоить возможное расширение войны и ее негативные последствия на Ближнем Востоке, Персидском заливе и на Индийском субконтиненте, и международные последствия этого. Поэтому, хотя в России скептически относятся к некоторым аспектам ЯПИ, но выступают против военных действий, чтобы снять данную озабоченность.

Сергей Караганов считает, что ситуация вокруг Ирана, которая чревата вооруженным конфликтом, почти неизбежная большая война или серия войн на Ближнем Востоке, - все это будет неизбежно выбрасывать метастазы силовых конфликтов на территорию России и ее соседей ${ }^{18}$.

Леонид Савин предупреждает о том, что при варианте широкой войны против Ирана понадобится создать дополнительные ближние рубежи, для чего необходимо будет склонять на свою сторону страны Кавказа и Центральной Азии. А в итоге затянется «петля Анаконды» вокруг России» ${ }^{19}$.

18 Караганов Сергей. Зачем оружие? - http://www. globalaffairs.ru/print/number/Zachem-oruzhie-15719, 28.10.2012.

19 Савин Леонид. Иранская Головоломка - http://www.fondsk. ru/news/2012/01/26/iranskaja-golovolomka.html, 26.01.2011.
Также российские власти в своих многочисленных позициях выступали против войны. В марте 2012 года Владимир Путин заявил; «Mы будем все делать для того, чтобы военного конфликта ни в самом Иране, ни вокруг Ирана не произошло. Для нас это имело бы очень негативные, прямые последствия» ${ }^{20}$. В ноября 2011 г. Сергей Лавров сказал; «Нама позиция на этот счет хорошо известна - это было бы очень серьезной ошибкой, чреватой непредсказуемыми последствиями» ${ }^{21}$.

Следует отметить, что в России многие, как в других странах, подчеркивают, что война против Ирана вряд ли приведет к остановке его ядерной программы, а лишь ускорят ее. Указывая на то, что против обретения Ираном ядерного оружия настроены практически все, Евгений Примаков утверждает, что силовые приемы, чтобы добиться этого, однозначно вызовут обратную реакцию 22.

Беспокоясь об обострении ситуации вокруг Ирана в 2012 году, Москва ставит перед собой некоторые задачи, чтобы контролировать последствия возможного нападения на Иран. К этим мерам относятся военные учения «Кавказ-2012» и «Взаимодействие$2012 »^{23}$ и также создание ситуационного центра Минобороны РФ, который, по словам Начальника Генштаба ВС РФ генерал армии Николай Макарова, может отслеживать обстановку в Иране в режиме реального времени ${ }^{24}$.

\section{3. Предотвращение выведения Ирана на орбиту США в результате оказываемого на него давления}

Некоторые русские политики и аналитики согласны с той точкой зрения, что основная причина политики давления Запада на Иран заключается

20 Путин: Россия сделает все, чтобы не допустить войны в Иране // РИА Новости - http://ria.ru/vybor2012 putin/20120302/583743901.html\#ixzz2MqiaLbFX, 2.03.2012.

21 Россия предостерегает Израиль от ударов по Ирану // Биби-си — http://www.bbc.co.uk/russian/russia/2011/11/111107 lavrov_iran_mistake.shtml, 7.11.2011.

22 Примаков Евгений. В стеклянном доме нельзя бросаться камнями — http://www.rg.ru/2012/02/29/iran.html, 29.02.2012.

23 Мухин Владимир. На «Кавказе-2012» повысили боеготовность - http://www.ng.ru/regions/2012-06-22/1_kavkaz.html, 22.06.2012.

24 Ситуация вокруг Ирана может получить развитие к лету, считает Макаров // РИА Новости - http://ria.ru/defense safety/20120214/565457850.html, 14.02.2012. 


\section{Национальная безопасность - № 2(31) • 2014}

в независимой внешней политике Тегерана и его несогласии с попытками Запада доминировать на Ближнем Востоке ${ }^{25}$.

С этой точки зрения, возникновение нынешнего кризиса вокруг ЯПИ стало следствием стратегической линии США на восстановление утраченного в конце 70-х годов прошлого столетия контроля над этой страной ${ }^{26}$.

Соответственно, можно предполагать, что давление на Иран и его Ядерную программу «инструмент» реализации американской экспансионистской политики. В связи с этим Примаков считает, что Вашингтон делает ставку на смену нынешнего режима в Сирии главным образом с целью изоляции Ирана ${ }^{27}$.

Юрий Баранчик относит причину серьезного давления на Иран к его положению как одному из центральных звеньев системы безопасности в Евразии. По его мнению, смена режима в Иране, к которой ведёт дело Вашингтон, и возвращение этой страны в орбиту США означали бы, что у евразийских гигантов, таких как Россия, возникли бы серьезные внешнеполитические осложнения ${ }^{28}$.

Так, понятно, что изменение нынешней внешнеполитической ориентации Ирана, посредством смены режима путем цветной революции, военного вторжения или капитуляции перед целенаправленным давлением Запада, в соответствии с политикой Запада не в интересах России.

Потому что, с одной стороны, Россия лишается потенциала в конкуренции/конфликте с Западом, и с другой стороны, усиление западного влияния в Иране принесет геополитический и геоэкономический ущерб России. Соответственно, Цви Маген считает, что война против Ирана на самом деле рассматривается как нападение на союзника России и члена политической оси во главе с Россией ${ }^{29}$.

25 Суслов Дмитрий. Иранский вопрос: предыстория и сущность — http://www.evrazia.org/article/2020, 30.07.2012.

26 Ситуационный анализ: «Иранский кризис: перспективы развития ситуации» - http://www.riss.ru/index.php/ actions/1299-xcvcbnm0987\#.Und0f_nfrMw, 28.03.2012.

27 Примаков Евгений // Там же.

28 Баранчик Юрий. Пойдут ли США на агрессию против Ирана? - http://www.fondsk.ru/news/2012/05/01/poydut-li-usana-agressiu-protiv-irana.html, 1.05.2012.

29 Magen Zvi. Possible Russian responses to an attack on Iran http://valdaiclub.com/asia/41340.html, 18.04.2012.

\section{Россия и переменная «США»}

Политика России по ЯПИ находится под влиянием не только принципа «Россия как великая независимая держава» и необходимости независимого действия на международной арене, но и ориентированного на партнерство принципа «Россия как нормативный член сообщества великих держав».

Поэтому, хотя Россия, с одной стороны, с акцентом на независимость внешней политики даже при обострении ситуаций продолжает свои отношения с Ираном, а именно это отличает ее подход от западного, с другой стороны, для Москвы сотрудничество с Западом для решения этой проблемы всегда было приоритетом и взаимодействие с Тегераном она рассматривала второстепенным ${ }^{30}$.

В соответствии с этим, характер отношений России и США был важной переменной в формировании политики Москвы по ЯПИ. Общие стратегические интересы в области безопасности, в том числе ядерного нераспространения привели Россию к сотрудничеству с США. А с другой стороны, их конкуренция/конфликт в геополитических и геоэкономических сферах были причиной того, что Москва полностью не соглашается с соображениями США.

Влияние таких «сотрудничества/конфронтации» на политику России по ЯПИ проявляется в колебании ее позиции в результате изменений в отношениях между Москвой и Вашингтоном в ходе президентства Путина, Медведева, и затем снова Путина.

Если 2002 год рассматривается как начало самого кризиса вокруг ЯПИ, заметно, что ухудшение отношений России и США в конце второго президентского срока Путина привело к тому, что не сформировалось тесное взаимодействие между ними в других областях, таких, как в ЯПИ. На практике, Россия выступала за осторожный подход к этой теме.

Однако, в период президентства Медведева, когда «перезагрузка» была на повестке дня, было видно более тесное сотрудничество между Москвой и Вашингтоном в различных вопросах, в том числе в ЯПИ. Заявление Медведева о приближении Ирана к обладанию потенциалом создания ядерного оружия, одобрение и реализация санкционных резолюций

\footnotetext{
30 Noori Alireza, Putin, Iran and the Issue of "Bigger Cake" in Russia's Foreign Policy - http://www.iranreview.org/content/ Documents/Putin_Iran_and the_Issue_of_\%E2\%80\%9CBigger_ Cake $\%$ E2\%80\%9D_in_Russia\%E2\%80\%99s_Foreign_Policy. htm, 14.04.2012.
} 
СБ ООН против Ирана, особенно резолюции № 1929 являются важными событими этого периода, которые выразились в серьезной критике Ирана ${ }^{31}$.

Недовольство Россией и США друг другом в период третьего срока Путина, в частности, в вопросах о европейской ПРО и игнорирование Вашингтоном интересов России на Ближнем Востоке, особенно в Ливии и Сирии еще больше усугубляли ситуацию в их отношениях. Это состояние повлияло на другие аспекты отношений России и США, например, возникло более заметное сопротивление Москвы давлению со стороны Запада по ЯПИ.

Явное несогласие России с односторонними санкциями и воинственными заявлениями в отношении Ирана является результатом данного изменения атмосферы. Таким образом, можно согласиться с идеей, что взлеты и падения в отношениях между Россией и США прямо и косвенно оказывают влияние на формирование политики Москвы по ЯПИ. Это воздействие было больше, чем воздействие двусторонних и региональных факторов.

Тем не менее, следует отметить, что давление на Иран по поводу его ядерной программы является лишь частью общей стратегической цели США поддерживать и укреплять их контроль над тенденциями на Ближнем Востоке. Очевидно, что Вашингтон, который рассматривает себя в качестве гегемона в международной системе, не принимает сопротивление других субъектов, включая Иран, своей экспансионистской политике.

Именно поэтому США с помощью различных механизмов, в том числе, психологического, в виде создания не соответствующих реальности изображений и пропаганды «ложных угроз», пытаются оказывать влияние на противников. Война против Афганистана и Ирака, вторжение в Ливию, давления на Сирию и Ирана являются недавними успешными примерами этой политики.

В то же время, Иран из-за несоответствия общим целям Вашингтона на Ближнем Востоке, больше других, и с самого начала своей революции был объектом различных инструментов давления. В настоящее время, такое давление сосредоточено на его ядерной программе. Вашингтон, в данном случае, кроме получения материальных ресурсов, осуществляет психологическая операция, чтобы «убедить»

\footnotetext{
31 Ahmadinejad slams Medvedev for siding with Iran's enemies // TV-Novosti — http://rt.com/news/ahmadinejad-medvedev-iranenemies/, 30.07.2010.
}

других о «необходимости» коллективного действия против Тегерана.

Создание и преувеличение «иранской угрозы» под предлогом озабоченности «международного сообщества», идентичность и члены которого не определены, имело успех на практике. Различные страны и организации охотно или невольно находились под влиянием этого психологической атмосферы.

\section{Россия, Иран и психологическая война Запада}

Хотя Россия иногда сопротивляется психологической войне и давлению Запада в отношении Ирана и его ядерной программы, кажется, что ее игра в целом сформировалась и выполнялась в рамках, сконструированных США. «Итоги» политики России по ЯПИ свидетельствуют о том, что это политика не отвечала интересам Москвы, а интересам Вашингтону.

Ход событий показывает, что США воспользовались Россией, чтобы легитимизировать незаконное давление на Тегеран, включая передачу досье Ирана из МАГАТЭ в СБ ООН, для принятия санкционных резолюций против Ирана и использование этих резолюций в качестве основы односторонних санкции, и следовательно, для ухудшения имиджа Ирана на международной арене.

Путин в своей Статье «Россия и меняющийся мир» указывает на этот ориентированный на собственные цели подход США: «есть одобрение Совета Безопасности ООН на ту или иную акиию хорошо, нет - создадим коалицию заинтересованных государств. И ударим» ${ }^{32}$. Хотя, здесь он имеет в виду Сирию, но Вашингтона использует эту процедуру по различным вопросам, включая ЯПИ.

В то время как, Иран находится под незаконным «легитимизированным» давлением, Россия сама хорошо знакома с политикой двойных стандартов США в различных международных вопросах, включая вопрос распространения оружия массового уничтожения (ОМУ). Например, США не только игнорирует широко распространенную ядерную деятельность Израиля, но даже препятствует международным усилиям, чтобы поставить эту деятельность под надзор МАГАТЭ.

Также, ход переговоров Ирана с группой «5+1» показывают, что не в интересах США решить проблему ЯПИ (по крайней мере в краткосрочной перспективе), а напротив, настаивает на ее продлении, потому что,

32 Путин Владимир // Там же. 


\section{Национальная безопасность - № 2(31) • 2014}

если это проблема решена, то США потеряет один из своих главных рычагов давления на Тегеран.

В связи с этим, акцент Москвы на то, что «Иран игнорирует требования международного сообщества» $)^{33}$, больше всего напоминает не соответствующий реальности сконструированный Вашингтоном образ Тегерана. Москве также хорошо известно, что использование термина «озабоченность международного сообщества» - инструмент США для создания напряженности и последовательного обеспечения политических и экономических интересов.

Считается, что война в Ираке и Афганистане привела к изменению регионального баланса сил в пользу Ирана, поэтому США намерены посредством новой войны восстановить этот баланс. Указывая то, что от роста напряжённости вокруг Ирана выиграют, прежде всего, американские нефтегазовые компании и военно-промышленный комплекс США, Сергей Правосудов полагает что возникнет кризис, с помощью которого США могут попытаться решить свои экономические проблемы ${ }^{34}$.

Позиции российских властей показывают, что они хорошо осознают эти общие стратегические цели. В феврале 2012 г. Владимир Путин сказал: «Я тоже считаю, что под видом борьбы за недопущение распространения оружия массового уничтожения за счет нового возможного члена ядерного клуба - за счет Ирана - предпринимаются попытки другого характера, иели ставятся другие - сменить режим» ${ }^{35}$.

Наличие такого осознания видно в противостоянии России политике Запада по сирийскому вопросу и в ее возмущении войной НАТО против Ливии. Хотя, дела Ливии, Сирии и, ранее, Афганистана и Ирака, отличаются от дела Ирана по форме, но природа политики США во всех этих случаях является ничем иным, как консолидированием и расширением своей гегемонии на «большом Ближнем Востоке».

Хотя в Москве осознают эти общие стратегические цели, но не был сделан значительный шаг по выведению политики России из сконструированных

33 МИД РФ: Иран игнорирует требования международного сообщества // Вести.Ru - http://www.vesti.ru/doc.html?id=680733, 13.01.2012.

34 Правосудов Сергей. Игра на Обострение: Почему США Выгодно, чтобы Иран Перекрыл Ормузский Пролив — http:// win.ru/ekonomicheskie-interesy/1326754144, 17.01.2012.

35 Путин: Запад пытается сменить режим в Иране // Би-би-си http://www.bbc.co.uk/russian/international/2012/02/120224_iran_ iaea_putin.shtml, 25.02.2012.
США рамок. Следует отметить, что в любом случае, даже если вопрос ЯПИ будет решен, США с целью продолжать оказывать давление на Тегеран, откроют другое дело против Ирана. В таком случае, России будет вынуждена следовать процедуре, испытанную в ЯПИ в новом деле.

\section{Обзор «поэтапного плана» России}

Предложение о поэтапном урегулировании ситуации вокруг ЯПИ является одной из немногих инициатив Москвы в этом деле. Хотя появление Москвы в качестве инициатора можно назвать положительным, обзор общих черт этого плана показывает, что он, подобно «практической» политике России, не выходит за рамки, сконструированные США. Считается даже, что сама Москва смотрит на этот план в качестве механизма увеличения «пространства для маневра», а не способа «решения проблем».

Прежде всего, следует отметить, что, хотя план в позитивном смысле делает акцент на механизм переговоров, но он не отрицает двойственную политику Запада «диалог-давление», которая не имеет никакой другой цели, кроме как навязать незаконные требования в виде, на первый взгляд логичных, переговоров.

Также не уделялось внимания тому, что целью этой политики было больше «давление», чем переговоры. Указывая на это намерение, Госсекретарь США Джон Керри после переговоров 7-8 ноября 2013 Ирана и «шестерки» в Женеве заявил, что целью США является сдерживание дальнейшей разработки Ираном ядерной программы, как первого шага на пути её полного прекращения ${ }^{36}$.

Так, можно утверждать, что в поэтапном плане не существует реалистического понимания, с одной стороны, Ирана и его ядерной программы и с другой стороны, причин давления на Иран и данную программу со стороны Запада. Согласно этому плану, Иран должен остановить некоторые ядерные деятельности и в обмен Запад сможет отменить санкции. Однако Иран неоднократно заявлял, что свои законные права в ядерной сфере, особенно право на обогащение урана в стране считает неоспоримыми ${ }^{37}$.

\footnotetext{
36 Kerry: United States not 'blind' or 'stupid' in Iran talks // Reuters — http://www.reuters.com/article/2013/11/10/us-irannuclear-kerry-idUSBRE9A909920131110, 10.11.2013.

37 Переговоры «шестерки» с Ираном начинаются в Женеве // РИА Новости — http://ria.ru/world/20131015/970012937.html, 15.10.2013.
} 
Другое дело, что упущение поэтапного плана заключается в том, что Иран санкции против себя, в основном, считает незаконными, и предложение «стимулов» Ирану в виде сокращения или устранения санкций, на самом деле, является лишь возвратом «прав», которых Иран незаконно был лишен.

Таким образом, в то время как, Россия делает акцент на принятие новых обязательств Ираном (включая, присоединение к Дополнительному протоколу к Соглашению о гарантиях с МАГАТЭ), предыдущие обязательства, взятые Тегераном, не только не помогли обеспечить его интересы, но привели к предъявлению новых требований и увеличению давления.

Следует отметить, что Иран во время президентства Мохаммада Хатами выполнял даже больше обязательства чем, те, которые упомянуты в Дополнительном протоколе, в том числе, он разрешил многократные инспекции, но не получил положительный и соответствующий ответ ${ }^{38}$.

С другой стороны, введение МАГАТЭ в качестве независимого исполнителя этого плана рассматривается спорным, потому что история его деятельности показывает зависимость МАГАТЭ от США. Критикуя доклад МАГАТЭ от 8 ноября 2011 года, Россия отметила эту зависимость, которая также нередко подвергается жесткой критике Тегерана.

Бывший иранский переговорщик по ядерной программе Хосейн Мусавиан (2003-2005) подтверждает, что даже если Тегеран готов к широкому сотрудничеству, у МАГАТЭ нет достаточного авторитета и полномочия, чтобы проверить прозрачность ЯПИ ${ }^{39}$.

Соответственно, русский план не уделял внимание тому факту, что здесь нет судьи, кроме США, чтобы подтвердить «убедительный» характер ответов Ирана. Но как свидетельствует история, некомпетентность этого «судьи» неоднократно доказывалась. Также нет четких критериев оценки «убедительности» ответов. Таким образом, вполне возможно, что после каждого ответа возникают новые вопросы и новые требования. Этот бесконечный цикл такой же, как и в переговорах между Тегераном и $5+1$.

Таким образом, возможность формирования бесконечного цикла, при котором возникает «все больше

\footnotetext{
38 Iran hysteria a cover for Israeli bomb - ex-Iranian diplomat // Russia Today - http://rt.com/news/iran-nuclear-israelmousavian-105/, 15.12.2012.

39 Interview with Hussein Mousavin about Iran's nuclear program // ir.voanews - http://ir.voanews.com/content/mousiaviab-englishinterveiw/1563829.html, 13.12.2012. (in persian).
}

и больше» вопросов является важным сходством между русским планом и американским подходом.

Также следует отметить, что Россия в своей инициативе не учитывала возможности для взаимной постановки вопросов, ответы на которые, безусловно, могут помочь реализации предполагаемой цели США укрепить режим нераспространения ядерного оружия и улучшить среду международной безопасности.

Например, почему великие державы используют понятия «нераспространение» и «разоружения» в качестве средства оказания давления на другие страны? Почему их политика в этой сфере является двойственной? В том числе, почему Россия и США не обращают внимания на ядерную программу Израиля? Почему великие державы, в том числе Россия и США, несмотря на лозунг нераспространения, стремятся развивать свой ядерный военный потенциал? Почему в условиях, когда ЯПИ находится под надзором МАГАТЭ, Израиль и США говорят о военном варианте? И многие другие вопросы.

\section{Необходимость принятия независимой позиции}

Несмотря на то, что власти России положительно оценивают свою промежуточную позицию по ЯПИ, это политика одновременно столкнулась с недоверием и критикой в Тегеране, Брюсселе и Вашингтоне. Например, позиция Москвы по санкциям иногда оценивалась как эксплуататорская ${ }^{40}$.

С одной стороны, согласием с санкциями СБ $\mathrm{OOH}$, Россия показывает Тегерану, что он нуждается в поддержке России, чтобы уменьшить оказываемое на него давление. И, с другой стороны, выступая против односторонних санкций, Россия дает понять Западу, что эффективность политики давления обусловлена помощью Москвы. Именно поэтому назвал «несколько шизофреническим» подход России к Ирану министр обороны США Роберт Гейтс ${ }^{41}$.

С другой стороны, отмечалось также, что правила игры в ЯПИ сформировались так, что кроме желаемого для Вашингтона, другого результата не будет. Ход событий показывает, что, хотя европей-

\footnotetext{
40 Parker John W. Russia and the Iranian Nuclear Program: Replay or Breakthrough? // Center for Strategic Research Institute for National Strategic Studies National Defense University. (9), March 2012. ст. 40.

41 Russia «Schizophrenic» on Iran // Reuters - http:// uk.reuters.com/article/2010/06/17/uk-usa-russia-iranidUKTRE65G5CK20100617, 17.06.2010.
} 


\section{Национальная безопасность - № 2(31) • 2014}

ские союзники Вашингтона благодаря сотрудничеству с ним по ЯПИ, более или менее, получили взаимную выгоду, однако Россия, несмотря на некоторое сотрудничество, включая в период президентства Медведева, не только не получила соответствующих выгод, но и иногда была названа в качестве проблемы.

Хотя Россия имеет ограничения на международной арене и особенно в отношениях с США, и логично, что в конфликте вокруг ЯПИ она склоняется к Западу, надо признать, что ее нынешняя политика противоречит претензии «России как великой независимой державы» и ее акценту на неприемлемость односторонних тенденций на международной арене.

С другой стороны, следует отметить, что, находясь под давлением Запада, Иран рассматривает Россию в качестве «балансера», и, если Москва не сможет сыграть эту роль, или если Тегеран в принципе не будет видеть необходимости в балансере, то ожидать ограничения роли России в ЯПИ будет естественно. В соответствии с этим и с учётом изменении ситуации в Иране после президентских выборов 2013 года, пересмотр политики Москвы кажется необходимым.

Деятельность Хасан Роухани как бывшего переговорщика Ирана с «шестеркой» и практическая политика его правительства в последние месяцы по ЯПИ, показывают что он прагматичным подходом поставил перед своей целью эффективный диалог с «главной стороной» - то есть, с Западом и, в частности с США. Он также показал, что не склонен использовать «промежуточную» роль России (и Китая) ${ }^{42}$.

В связи с этим Владимир Орлов утверждал, что России все же следует посмотреть на сегодняшний Иран как на своего серьезного и долгосрочного партнера в регионе. Такие попытки периодически происходят, но то и дело прерываются из-за, по его мнению, ложной боязни обидеть американцев ${ }^{43}$.

Следует отметить, что зависимость нынешней политики России по ЯПИ от переменной «США» приводит к таким ущербам в отношениях между Тегераном

42 Noori Alireza. Russia and Iran's Nuclear Dossier in Rouhani's Tenure: The Need for a Change - http://www.iranreview.org/ content/Documents/Russia-and-Iran-s-Nuclear-Dossier-inRouhani-s-Tenure-The-Need-for-a-Change.htm, 4.07.2013.

43 Орлов Владимир. Лабиринт, которого нет; Зачем и кому нужна война с Ираном - http:/globalaffairs.ru/number/Labirintkotorogo-net-15460, 19.02.2012. и Москвой как, отмена поставок систем ПВО С-300 Ирану Россией и несогласие Москвы с постоянным членством Ирана в Шанхайской организации сотрудничества (ШОС) в связи с действующими санкциями против Ирана. Очевидно, что эти события больше, чем какие-либо другие, были в пользу Запада.

Хотя 24 ноября 2013 в Женеве было достигнуто соглашение между Ираном и «шестеркой» по ЯПИ, Россия знает, что выполнение соглашения и проверка его реализации «тяжелее», чем достижение самого соглашения. Более важно, что в случае, если не реализуется данное соглашение, не будет неожиданностью, если ситуация станет более сложной, давление - более жестким и военный вариант более вероятным.

В этих условиях и учитывая, что ЯПИ превратилась в критерий для измерения мощности Ирана, Запада, Израиля, региональных арабских стран и России, Москва должна придать большую «прозрачность» своей позиции и большую «реальность» своей практической политике по ЯПИ ${ }^{44}$.

\section{Заключение}

Занимая промежуточную позицию в десятилетнем конфликте вокруг ЯПИ, Россия старалась одновременно обеспечить три своих важных интереса, предотвращение обладания Тегераном ядерного оружия, предотвращение войны против Ирана и предотвращение выведения Ирана на орбиту США в результате оказываемого на него давления. Хотя Москва считает свою политику принципиальной, существуют некоторые дефекты, наиболее важными из которых являются зависимость от переменной «США» и то же время, представление о малом значении другой части этого уравнения - Ирана.

Хотя возможности России ограничены, следует признать, что ее политика по ЯПИ не соответствует ее претензии как «великой независимой державы» и акцентом на неприемлемость экспансионизма США. История присутствия России в переговорах в формате « $5+1 »$, ее голосование в СБ ООН и ее не очень согласованный поэтапный план показывают, что, во-первых, политика России действовала в сконструированных США рамках и, во-вторых, осознание

\footnotetext{
44 Noori Alireza. Iran's Position in Russia's Incoherent Middle East Policy — http://www.iranreview.org/content/Documents/ Iran-s-Position-in-Russia-s-Incoherent-Middle-East-Policy.htm, 21.11.2013.
} 
Москвы общих стратегических целей давления на Тегеран не проявилось в ее «практической» политике.

Таким образом, хотя некоторое время политика России приводила к задержке и снижению давления, в конечном счете, она не смогла внести значительный вклад в логическое разрешение проблемы ЯПИ. И даже иногда США использовали Россию, чтобы легитимизировать незаконное давление на Тегеран. Соответственно, с учетом того, что подписание соглашения 24 ноября 2013 в Женеве - всего лишь первый шаг, а не всеобъемлющее соглашение, кажется, что Москве необходимо переоценивать свою политику, чтобы сохранить свои позиции и обеспечить свои интересы.

\section{Библиография}

1. Арбатов А. Г. Ползучий Кризис // Азия и Африка сегодня. № 8. Август и Сентябрь 2012.

2. Баранчик Юрий. Пойдут ли США на агрессию против Ирана? // http://www.fondsk.ru/news/2012/05/01/ poydut-li-usa-na-agressiu-protiv-irana.html, 1.05.2012.

3. Глава МИД РФ Сергей Лавров: итоги года // http://www.interfax.ru/txt.asp?id=283171, 27.11.2012.

4. Караганов Сергей. Зачем оружие? // http://www.globalaffairs.ru/print/number/Zachem-oruzhie-15719, 28.10.2012.

5. Комментарий Департамента информации и печати МИД России относительно вышедшего 8 ноября нового доклада Гендиректора МАГАТЭ Ю.Амано по иранской ядерной программе // Пресс-служба МИД России. 1737 // http://www.mid.ru/brp_4.nsf/0/7AA0429FED84FBCD44257943005CC5EA, 9.11.2011.

6. Лавров увидел в санкциях США против Ирана и Сирии угрозу российскому бизнесу // http://lenta.ru/ news/2012/09/08/interests/, 8.09.2012.

7. Лавров: ни у кого нет данных о военной направленности программы Ирана // http://ria.ru/ world/20131008/968628455.html, 8.10.2013.

8. Манина Дарья. Итоги Года. Чем обогащается Иран // http://rus.ruvr.ru/2012_12_22/ITOGI-GODA-CHemobogashhaetsja-Iran/, 22.11.2012.

9. Медведев: Иран Приближается к Возможности Создания Ядерного Оружия // http://www.rian.ru/ world/20100712/253947885.html, 12.07.2010.

10. МИД РФ: Иран игнорирует требования международного сообщества // http://www.vesti.ru/doc. html?id=680733, 13.01.2012.

11. Милов Владимир. Сказка о злобном Западе // http://www.vedomosti.ru/opinion/news/1518088/vostok_est_ vostok, 29.02.2012.

12. Мухин Владимир. На «Кавказе-2012» повысили боеготовность // http://www.ng.ru/regions/2012-06-22/1_ kavkaz.html, 22.06.2012.

13. Николаева Карина и Ковалев Георгий. Иранский Компромисс // http://www.politcom.ru/15054.html, 19.12.2012.

14. Орлов Владимир. Лабиринт, которого нет; Зачем и кому нужна война с Ираном // http://globalaffairs.ru/ number/Labirint-kotorogo-net-15460, 19.02.2012.

15. Переговоры «шестерки» с Ираном начинаются в Женеве // http://ria.ru/world/20131015/970012937.html, 15.10.2013.

16. Позиция «шестерки» в Алма-Ате должна быть привлекательна для Ирана // http://www.interfax.ru/txt. asp?id=290722, 15.02.2013.

17. Правосудов Сергей. Игра на Обострение: Почему США Выгодно, чтобы Иран Перекрыл Ормузский Пролив // http://win.ru/ekonomicheskie-interesy/1326754144, 17.01.2012.

18. Примаков Евгений. В стеклянном доме нельзя бросаться камнями // http://www.rg.ru/2012/02/29/iran.html, 29.02.2012.

19. Путин Владимир. Россия и Меняющийся Мир // http://www.mn.ru/politics/20120227/312306749.html, 27.02.2012.

20. Путин признает право Ирана на мирный атом // http://www.interfax.ru/world/news.asp?id=328711, 13.08.2013.

21. Путин: Запад пытается сменить режим в Иране // http://www.bbc.co.uk/russian/international/2012/02/120224 iran_iaea_putin.shtml, 25.02.2012. 


\section{Национальная безопасность - № 2(31) • 2014}

22. Путин: Россия поддерживает право Ирана на мирный атом // http://www.vesti.ru/doc.html?id=815336\&cid=5, 7.06.2012.

23. Путин: Россия сделает все, чтобы не допустить войны в Иране // http://ria.ru/vybor2012 putin/20120302/583743901.html\#ixzz2MqiaLbFX, 2.03.2012.

24. Россия предостерегает Израиль от ударов по Ирану // http://www.bbc.co.uk/russian/russia/2011/11/111107_ lavrov_iran_mistake.shtml, 7.11.2011.

25. РФ рассчитывает на выполнение Ираном обязательств по ядерной программе // http://ria.ru/ politics/20120417/628229087.html, 17.04.2012.

26. РФ рассчитывает на выполнение Ираном обязательств по ядерной программе // http://ria.ru/ politics/20120417/628229087.html, 17.03.2012

27. Савин Леонид. Иранская Головоломка // http://www.fondsk.ru/news/2012/01/26/iranskaja-golovolomka.html, 26.01.2012.

28. Седов Дмитрий. МАГАТЭ и «туалетное дело» // http://www.fondsk.ru/news/2012/02/23/magate-i-tualetnoedelo.html, 23.02.2012.

29. Ситуационный анализ: «Иранский кризис: перспективы развития ситуации» // http://www.riss.ru/index. php/actions/1299-xcvcbnm0987\#.Und0f_nfrMw, 28.03.2012.

30. Ситуация вокруг Ирана может получить развитие к лету, считает Макаров // http://ria.ru/defense safety/20120214/565457850.html, 14.02.2012.

31. Суслов Дмитрий. Иранский вопрос: предыстория и сущность // http://www.evrazia.org/article/2020, 30.07.2012.

32. Ahmadinejad slams Medvedev for siding with Iran's enemies // http://rt.com/news/ahmadinejad-medvedev-iranenemies/, 30.07.2010.

33. Iran hysteria a cover for Israeli bomb-ex-Iranian diplomat // http://rt.com/news/iran-nuclear-israel-mousavian-105/, 15.12.2012.

34. Kerry: United States not 'blind' or 'stupid' in Iran talks // http://www.reuters.com/article/2013/11/10/us-irannuclear-kerry-idUSBRE9A909920131110, 10.11.2013.

35. MagenZvi.PossibleRussian responses to anattack on Iran //http://www.inss.org.il/index.aspx?id=4538\&articleid=2468, 17.04.2012.

36. Noori Alireza, Putin, Iran and the Issue of "Bigger Cake" in Russia's Foreign Policy // http://www.iranreview. org/content/Documents/Putin_Iran_and_the_Issue_of_\%E2\%80\%9CBigger_Cake\%E2\%80\%9D_in_ Russia\%E2\%80\%99s_Foreign_Policy.htm, 14.04.2012.

37. Noori Alireza. Russia and Iran's Nuclear Dossier in Rouhani's Tenure: The Need for a Change // http://www. iranreview.org/content/Documents/Russia-and-Iran-s-Nuclear-Dossier-in-Rouhani-s-Tenure-The-Need-for-aChange.htm, 4.07.2013.

38. Noori Alireza. Iran's Position in Russia's Incoherent Middle East Policy // http://www.iranreview.org/content/ Documents/Iran-s-Position-in-Russia-s-Incoherent-Middle-East-Policy.htm, 21.11.2013.

39. Parker John W. Russia and the Iranian Nuclear Program: Replay or Breakthrough? // Center for Strategic Research Institute for National Strategic Studies National Defense University. (9), March 2012.

40. Russia "Schizophrenic" on Iran // http://uk.reuters.com/article/2010/06/17/uk-usa-russia-iranidUKTRE65G5CK20100617, 17.06.2010.

41. Yevseyev Vladimir. Tough talks with Iran lie ahead in Moscow // http://valdaiclub.com/asia/44481.html, 15.06.2012.

42. Interview with Hussein Mousavin about Iran's nuclear program // http://ir.voanews.com/content/mousiaviabenglish-interveiw/1563829.html, 13.12.2012. (in Persian).

43. О.Г. Карпович Ядерная программа Ирана в фокусе внешней политики США// Национальная безопасность / nota bene. - 2013. - 1. - C. 128 - 130. DOI: 10.7256/2073-8560.2013.01.11.

44. Бобкин Н.Н. Президентские выборы в Иране — 2013 // NB: Международные отношения. — 2013. — 2. — C. 80 - 98. URL: http://www.e-notabene.ru/wi/article_774.html

45. Перов Е.В. Теория и анализ социальной конфликтогенности общества // NB: Национальная безопасность. — 2013. - 5. — C. 67 - 141. URL: http://www.e-notabene.ru/nb/article_2308.html 


\section{References}

1. Arbatov A. G. Polzuchii Krizis // Aziya i Afrika segodnya. № 8. Avgust i Sentyabr’ 2012.

2. Baranchik Yurii. Poidut li SShA na agressiyu protiv Irana? // http://www.fondsk.ru/news/2012/05/01/poydut-liusa-na-agressiu-protiv-irana.html, 1.05.2012.

3. Glava MID RF Sergei Lavrov: itogi goda // http://www.interfax.ru/txt.asp?id=283171, 27.11.2012.

4. Karaganov Sergei. Zachem oruzhie? // http://www.globalaffairs.ru/print/number/Zachem-oruzhie-15719, 28.10.2012.

5. Kommentarii Departamenta informatsii i pechati MID Rossii otnositel'no vyshedshego 8 noyabrya novogo doklada Gendirektora MAGATE Yu.Amano po iranskoi yadernoi programme // Press-sluzhba MID Rossii. 1737 // http:// www.mid.ru/brp_4.nsf/0/7AA0429FED84FBCD44257943005CC5EA, 9.11.2011.

6. Lavrov uvidel v sanktsiyakh SShA protiv Irana i Sirii ugrozu rossiiskomu biznesu // http://lenta.ru/news/2012/09/08/ interests/, 8.09.2012.

7. Lavrov: ni u kogo net dannykh o voennoi napravlennosti programmy Irana // http://ria.ru/world/20131008/968628455. html, 8.10.2013.

8. Manina Dar'ya. Itogi Goda. Chem obogashchaetsya Iran// http://rus.ruvr.ru/2012_12_22/ITOGI-GODA-CHemobogashhaetsja-Iran/, 22.11.2012.

9. Medvedev: Iran Priblizhaetsya k Vozmozhnosti Sozdaniya Yadernogo Oruzhiya // http://www.rian.ru/ world/20100712/253947885.html, 12.07.2010.

10. MID RF: Iran ignoriruet trebovaniya mezhdunarodnogo soobshchestva // http://www.vesti.ru/doc.html?id=680733, 13.01.2012.

11. Milov Vladimir. Skazka o zlobnom Zapade// http://www.vedomosti.ru/opinion/news/1518088/vostok_est_vostok, 29.02.2012.

12. Mukhin Vladimir. Na “Kavkaze-2012" povysili boegotovnost'// http://www.ng.ru/regions/2012-06-22/1_kavkaz. html, 22.06.2012.

13. Nikolaeva Karina i Kovalev Georgii. Iranskii Kompromiss // http://www.politcom.ru/15054.html, 19.12.2012.

14. Orlov Vladimir. Labirint, kotorogo net; Zachem i komu nuzhna voina s Iranom // http:/globalaffairs.ru/number/ Labirint-kotorogo-net-15460, 19.02.2012.

15. Peregovory "shesterki" s Iranom nachinayutsya v Zheneve // http://ria.ru/world/20131015/970012937.html, 15.10.2013.

16. Pozitsiya “shesterki” v Alma-Ate dolzhna byt' privlekatel'na dlya Irana // http://www.interfax.ru/txt.asp?id=290722, 15.02.2013.

17. Pravosudov Sergei. Igra na Obostrenie: Pochemu SShA Vygodno, chtoby Iran Perekryl Ormuzskii Proliv // http:// win.ru/ekonomicheskie-interesy/1326754144, 17.01.2012.

18. Primakov Evgenii. V steklyannom dome nel'zya brosat'sya kamnyami // http://www.rg.ru/2012/02/29/iran.html, 29.02.2012.

19. Putin Vladimir. Rossiya i Menyayushchiisya Mir // http://www.mn.ru/politics/20120227/312306749.html, 27.02.2012.

20. Putin priznaet pravo Irana na mirnyi atom // http://www.interfax.ru/world/news.asp?id=328711, 13.08.2013.

21. Putin: Zapad pytaetsya smenit' rezhim v Irane // http://www.bbc.co.uk/russian/international/2012/02/120224 iran_iaea_putin.shtml, 25.02.2012.

22. Putin: Rossiya podderzhivaet pravo Irana na mirnyi atom // http://www.vesti.ru/doc.html?id=815336\&cid=5, 7.06.2012.

23. Putin: Rossiya sdelaet vse, chtoby ne dopustit' voiny v Irane// http://ria.ru/vybor2012_putin/20120302/583743901. html\#ixzz2MqiaLbFX, 2.03.2012.

24. Rossiya predosteregaet Izrail' ot udarov po Iranu // http://www.bbc.co.uk/russian/russia/2011/11/111107_lavrov_ iran_mistake.shtml, 7.11.2011.

25. RF rasschityvaet na vypolnenie Iranom obyazatel'stv po yadernoi programme // http://ria.ru/ politics/20120417/628229087.html, 17.04.2012. 


\section{Национальная безопасность - № 2(31) • 2014}

26. RF rasschityvaet na vypolnenie Iranom obyazatel'stv po yadernoi programme // http://ria.ru/ politics/20120417/628229087.html, 17.03.2012

27. Savin Leonid. Iranskaya Golovolomka // http://www.fondsk.ru/news/2012/01/26/iranskaja-golovolomka.html, 26.01.2012.

28. Sedov Dmitrii. MAGATE i «tualetnoe delo»// http://www.fondsk.ru/news/2012/02/23/magate-i-tualetnoe-delo. html, 23.02.2012.

29. Situatsionnyi analiz: «Iranskii krizis: perspektivy razvitiya situatsii»// http://www.riss.ru/index.php/actions/1299_ xcvcbnm0987\#.Und0f_nfrMw, 28.03.2012.

30. Situatsiya vokrug Irana mozhet poluchit' razvitie k letu, schitaet Makarov // http://ria.ru/defense safety/20120214/565457850.html, 14.02.2012.

31. Suslov Dmitrii. Iranskii vopros: predystoriya i sushchnost'// http://www.evrazia.org/article/2020, 30.07.2012.

32. Ahmadinejad slams Medvedev for siding with Iran's enemies // http://rt.com/news/ahmadinejad-medvedev-iranenemies/, 30.07.2010.

33. Iran hysteria a cover for Israeli bomb-ex-Iranian diplomat // http://rt.com/news/iran-nuclear-israel-mousavian-105/, 15.12.2012.

34. Kerry: United States not 'blind' or 'stupid' in Iran talks // http://www.reuters.com/article/2013/11/10/us-irannuclear-kerry-idUSBRE9A909920131110, 10.11.2013.

35. MagenZvi. PossibleRussian responses to an attack on Iran //http://www.inss.org.il/index.aspx?id=4538\&articleid=2468, 17.04.2012.

36. Noori Alireza, Putin, Iran and the Issue of "Bigger Cake" in Russia's Foreign Policy // http://www.iranreview. org/content/Documents/Putin_Iran_and_the_Issue_of_\%E2\%80\%9CBigger_Cake\%E2\%80\%9D_in_ Russia\%E2\%80\%99s_Foreign_Policy.htm, 14.04.2012.

37. Noori Alireza. Russia and Iran's Nuclear Dossier in Rouhani's Tenure: The Need for a Change // http://www. iranreview.org/content/Documents/Russia-and-Iran-s-Nuclear-Dossier-in-Rouhani-s-Tenure-The-Need-for-aChange.htm, 4.07.2013.

38. Noori Alireza. Iran's Position in Russia's Incoherent Middle East Policy // http://www.iranreview.org/content/ Documents/Iran-s-Position-in-Russia-s-Incoherent-Middle-East-Policy.htm, 21.11.2013.

39. Parker John W. Russia and the Iranian Nuclear Program: Replay or Breakthrough? // Center for Strategic Research Institute for National Strategic Studies National Defense University. (9), March 2012.

40. Russia "Schizophrenic" on Iran // http://uk.reuters.com/article/2010/06/17/uk-usa-russia-iranidUKTRE65G5CK20100617, 17.06.2010.

41. Yevseyev Vladimir. Tough talks with Iran lie ahead in Moscow // http://valdaiclub.com/asia/44481.html, 15.06.2012.

42. Interview with Hussein Mousavin about Iran's nuclear program // http://ir.voanews.com/content/mousiaviabenglish-interveiw/1563829.html, 13.12.2012. (in Persian).

43. O.G. Karpovich Yadernaya programma Irana v fokuse vneshnei politiki SShA // Natsional'naya bezopasnost' / nota bene. - 2013. - 1. - C. 128 - 130. DOI: 10.7256/2073-8560.2013.01.11.

44. Bobkin N.N. Prezidentskie vybory v Irane - 2013 // NB: Mezhdunarodnye otnosheniya. — 2013. — 2. — C. 80 - 98. URL: http://www.e-notabene.ru/wi/article_774.html

45. Perov E.V. Teoriya i analiz sotsial'noi konfliktogennosti obshchestva // NB: Natsional'naya bezopasnost'. — 2013. — 5. — C. 67 - 141. URL: http://www.e-notabene.ru/nb/article_2308.html 